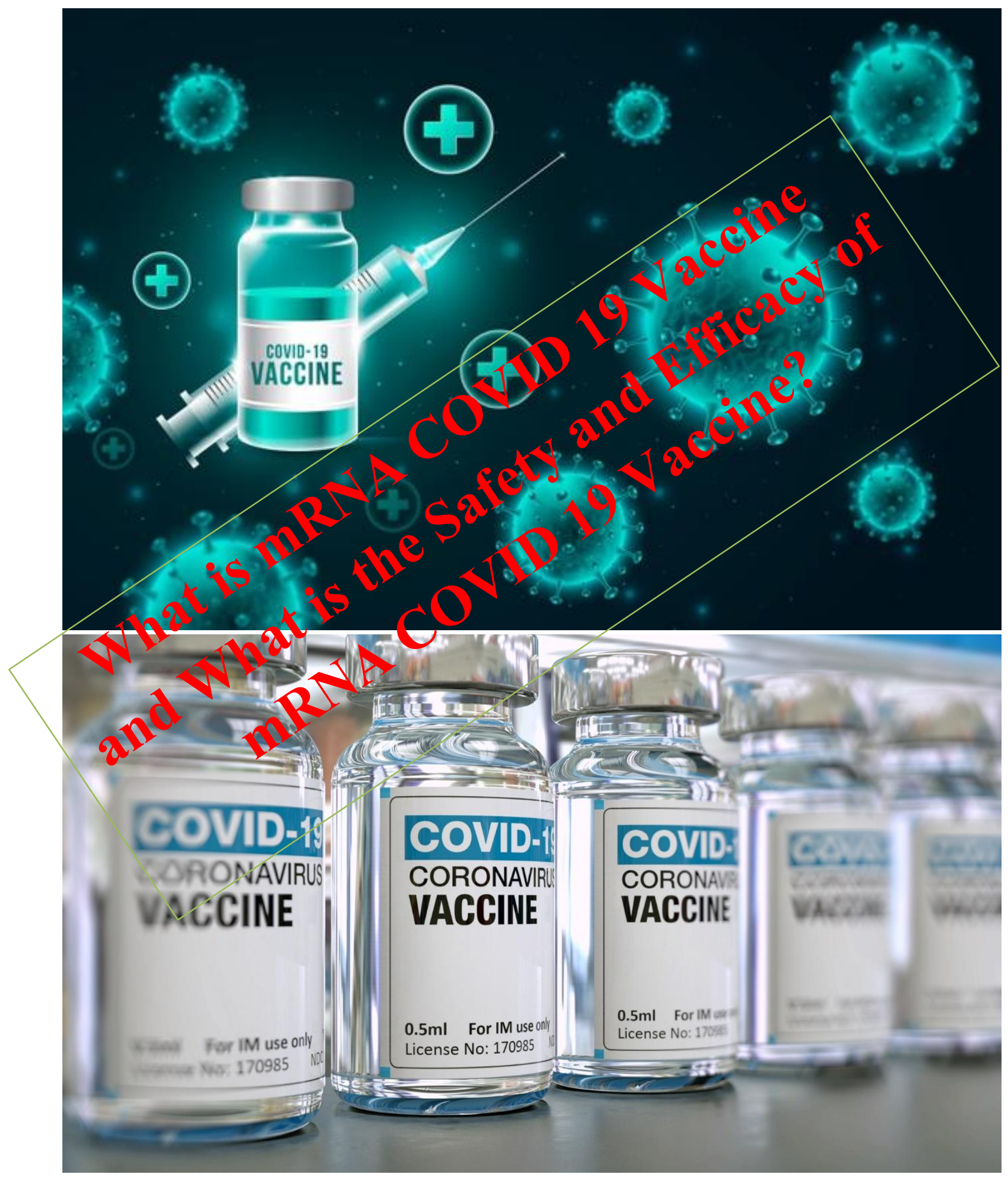

Dattatreya Mukherjee 
A Short Note on mRNA Vaccine

Only used for Awareness Purpose

Author: Dattatreya Mukherjee, MBBS Student, Jinan University,

P.R China

Sasthya Sahay Health Care Research Institute

Publisher: Sasthya Sahay Publication

Copy Right 4.0 International Licence 


\section{What is mRNA COVID 19 Vaccine and What is the safety and Efficacy of mRNA COVID 19 Vaccine?}

\section{Dattatreya Mukherjee, Jinan University, P.R China}

Any of the first COVID-19 vaccines approved for use in the U.S. is messenger RNA (mRNA) vaccines, also called mRNA vaccines. In order to activate an immune response and create immunity to SARS-CoV-2, the virus which causes COVID-19, mRNA vaccines take advantage of the mechanism that cells use to produce proteins. Many vaccines, on the other hand, use weakened or inactivated forms or elements of the pathogen causing disease to induce the immune system of the body to generate antibodies.

Mechanism of Action: mRNA vaccines have strands of genetic material called mRNA inside a special coating. That coating protects the mRNA from enzymes in the body that would otherwise break it down. It also helps the mRNA enter the dendritic cells and macrophages in the lymph node near the vaccination site.

mRNA can most easily be described as instructions for the cell on how to make a piece of the "spike protein" that is unique to SARS-CoV-2. Since only part of the protein is made, it does not do any harm to the person vaccinated but it is antigenic.

After the piece of the spike protein is made, the cell breaks down the mRNA strand and disposes of them using enzymes in the cell. It is important to note that the mRNA strand never enters the cell's nucleus or affects genetic 
material. This information helps counter misinformation about how mRNA vaccines alter or modify someone's genetic makeup.

Once displayed on the cell surface, the protein or antigen causes the immune system to begin producing antibodies and activating T-cells to fight off what it thinks is an infection. These antibodies are specific to the SARS-CoV-2 virus, which means the immune system is primed to protect against future infection.

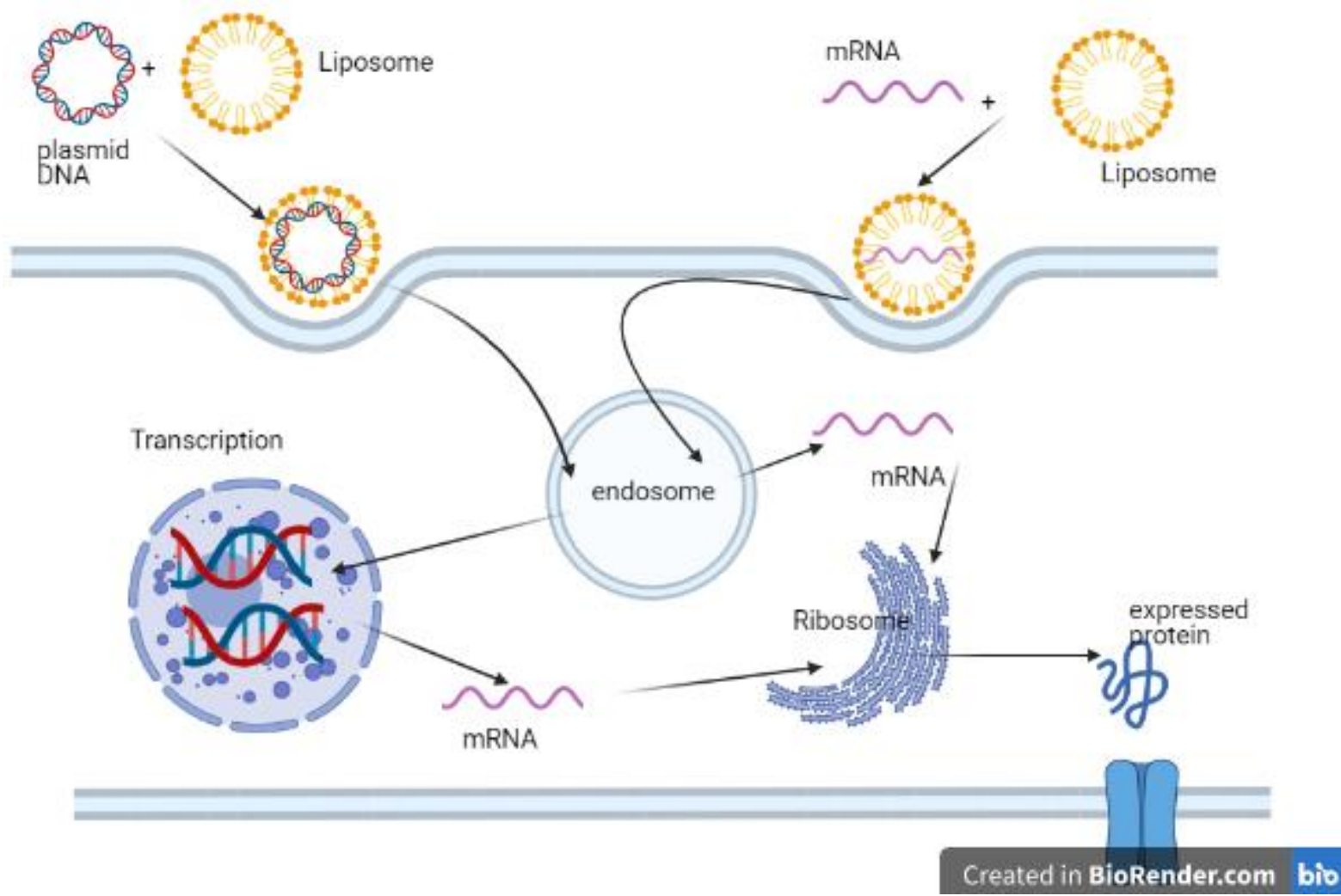

Mechanism of mRNA Vaccine

Safety: The COVID-19 mRNA vaccines underwent the same comprehensive safety review as other vaccines before the Food and Drug Administration approved them for use in the United States. This entails major clinical trials and a safety testing board's analysis of results. 
Live vaccines are also a problem for patients. mRNA vaccines are not live vaccines and do not use an infectious factor, so the person vaccinated has no chance of developing disease.

Fernando P Polak et al: In people 16 years of age or older, a two-dose regimen of BNT162b2 conferred 95\% protection against Covid-19. The protection was comparable to that of other viral vaccines for a median duration of 2 months. (Funded by BioNTech and Pfizer; NCT04368728, ClinicalTrials.gov number.)

Edward E Walsh et Al: Protection and immunogenicity results from this U.S. phase 1 study of two candidate vaccines in younger and older adults, adding to earlier interim safety and immunogenicity data for BNT162b1 in younger adults from studies in Germany and the U.S., encourage the selection of BNT162b2 for progression to a pivotal phase 2-3 assessment of safety and efficacy. (Funded by BioNTech and Pfizer; NCT04368728, ClinicalTrials.gov number.)

Denis Y Logunov et al.: The vector-based COVID-19 heterologous rAd26 and rAd5 vaccines have a decent safety profile and have induced robust humoral and cellular immune responses in participants. The efficacy of this vaccine for COVID-19 prevention needs to be more studied.

Evan J Anderson et al: Adverse effects associated with the mRNA-1273 vaccine were mostly mild to moderate in this small sample affecting older adults. In a phase 3 vaccine trial, the $100 \mu \mathrm{g}$ dose caused higher binding and neutralising antibody titers than the $25 \mu \mathrm{g}$ dose, which encourages the use of the $100 \mu \mathrm{g}$ dose. (Funded by the National Allergy and Infectious Diseases Institute and others; number of mRNA-1273 Research ClinicalTrials.gov, NCT04283461.). 
Benefits of mRNA Vaccine: Compared to other types of vaccines, mRNA vaccines have many advantages, including the use of a non-infectious ingredient, faster development cycles, and the ability to target several diseases. Using a DNA prototype and readily available materials, mRNA vaccines can be produced in a laboratory. This ensures that it is possible to standardise and scale up the procedure, allowing the production of vaccines easier than conventional approaches. Moreover, DNA and RNA vaccines will usually be moved to the clinic for initial monitoring as soon as possible. The mRNA vaccine technology could allow one vaccine to target several diseases in the future.

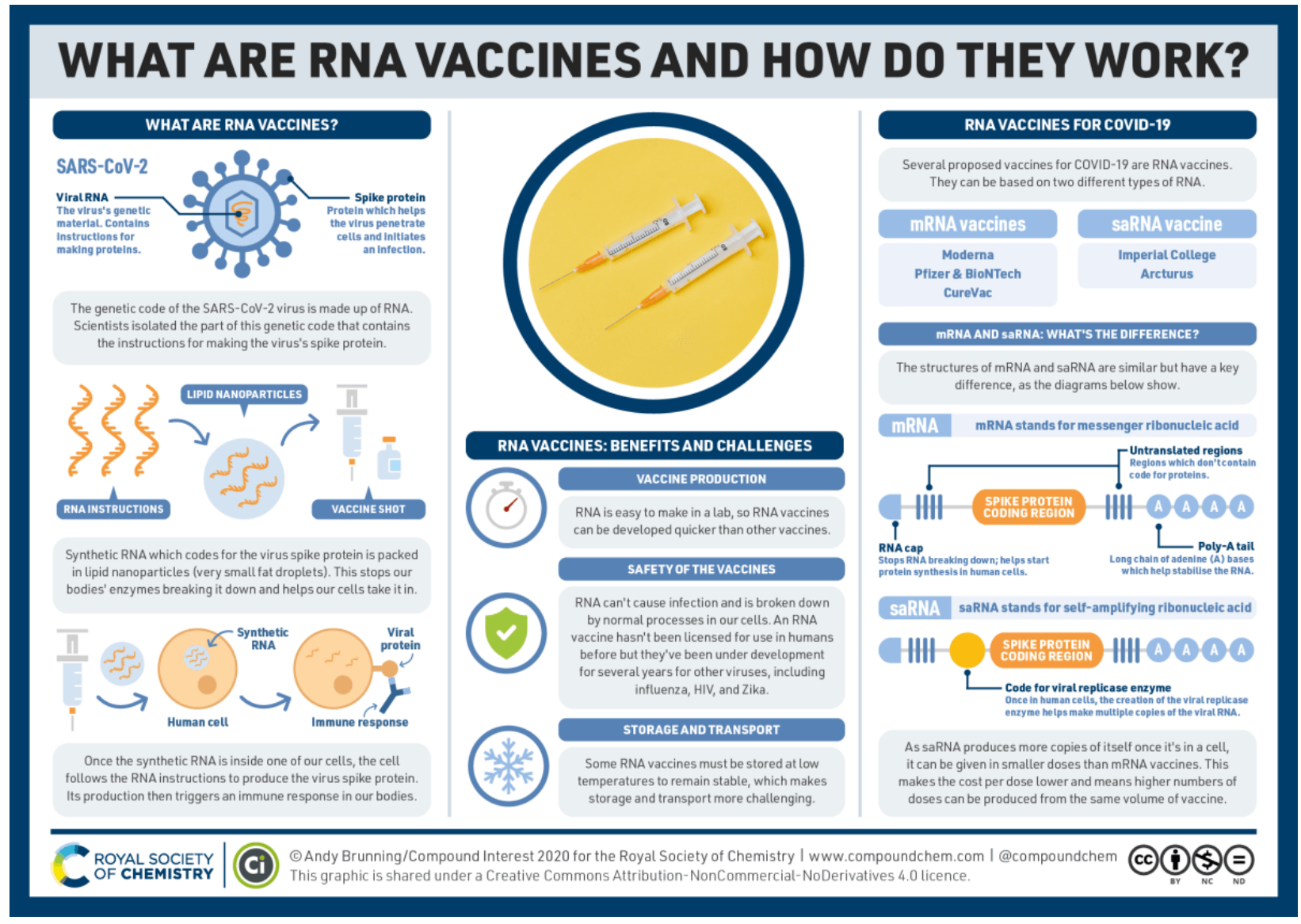




\section{References:}

1. Polack FP, Thomas SJ, Kitchin N, Absalon J, Gurtman A, Lockhart S, Perez JL, Pérez Marc G, Moreira ED, Zerbini C, Bailey R, Swanson KA, Roychoudhury S, Koury K, Li P, Kalina WV, Cooper D, Frenck RW Jr, Hammitt LL, Türeci Ö, Nell H, Schaefer A, Unal S, Tresnan DB, Mather S, Dormitzer PR, Şahin U, Jansen KU, Gruber WC; C4591001 Clinical Trial Group. Safety and Efficacy of the BNT162b2 mRNA Covid-19 Vaccine. N Engl J Med. 2020 Dec 31;383(27):26032615. doi: 10.1056/NEJMoa2034577. Epub 2020 Dec 10. PMID: 33301246; PMCID: PMC7745181.

2. Walsh EE, Frenck RW Jr, Falsey AR, Kitchin N, Absalon J, Gurtman A, Lockhart S, Neuzil K, Mulligan MJ, Bailey R, Swanson KA, Li P, Koury K, Kalina W, Cooper D, Fontes-Garfias C, Shi PY, Türeci Ö, Tompkins KR, Lyke KE, Raabe V, Dormitzer PR, Jansen KU, Şahin U, Gruber WC. Safety and Immunogenicity of Two RNA-Based Covid-19 Vaccine Candidates. N Engl J Med. 2020 Dec 17;383(25):2439-2450. doi: 10.1056/NEJMoa2027906. Epub 2020 Oct 14. PMID: 33053279; PMCID: PMC7583697

3. Logunov DY, Dolzhikova IV, Zubkova OV, Tukhvatulin AI, Shcheblyakov DV, Dzharullaeva AS, Grousova DM, Erokhova AS, Kovyrshina AV, Botikov AG, Izhaeva FM, Popova O, Ozharovskaya TA, Esmagambetov IB, Favorskaya IA, Zrelkin DI, Voronina DV, Shcherbinin DN, Semikhin AS, Simakova YV, Tokarskaya EA, Lubenets NL, Egorova DA, Shmarov MM, Nikitenko NA, Morozova LF, Smolyarchuk EA, Kryukov EV, Babira VF, Borisevich SV, Naroditsky BS, Gintsburg AL. Safety and immunogenicity of an rAd26 and rAd5 vector-based heterologous prime-boost COVID-19 vaccine in two formulations: two open, non-randomised phase 1/2 studies from Russia. Lancet. 2020 Sep 26;396(10255):887-897. doi: 10.1016/S0140-6736(20)31866-3. Epub 2020 Sep 4. Erratum in: Lancet. 2021 Jan 9;397(10269):98. PMID: 32896291; PMCID: PMC7471804.

4. Anderson EJ, Rouphael NG, Widge AT, Jackson LA, Roberts PC, Makhene M, Chappell JD, Denison MR, Stevens LJ, Pruijssers AJ, McDermott AB, Flach B, Lin BC, Doria-Rose NA, O'Dell S, Schmidt SD, Corbett KS, Swanson PA 2nd, Padilla M, Neuzil KM, Bennett H, Leav B, Makowski M, Albert J, Cross K, Edara 
VV, Floyd K, Suthar MS, Martinez DR, Baric R, Buchanan W, Luke CJ, Phadke VK, Rostad CA, Ledgerwood JE, Graham BS, Beigel JH; mRNA-1273 Study Group. Safety and Immunogenicity of SARS-CoV-2 mRNA-1273 Vaccine in Older Adults. N Engl J Med. 2020 Dec 17;383(25):2427-2438. doi:

10.1056/NEJMoa2028436. Epub 2020 Sep 29. PMID: 32991794; PMCID: PMC7556339.

5. https://www.compoundchem.com/2020/12/02/rna-vaccines/ 